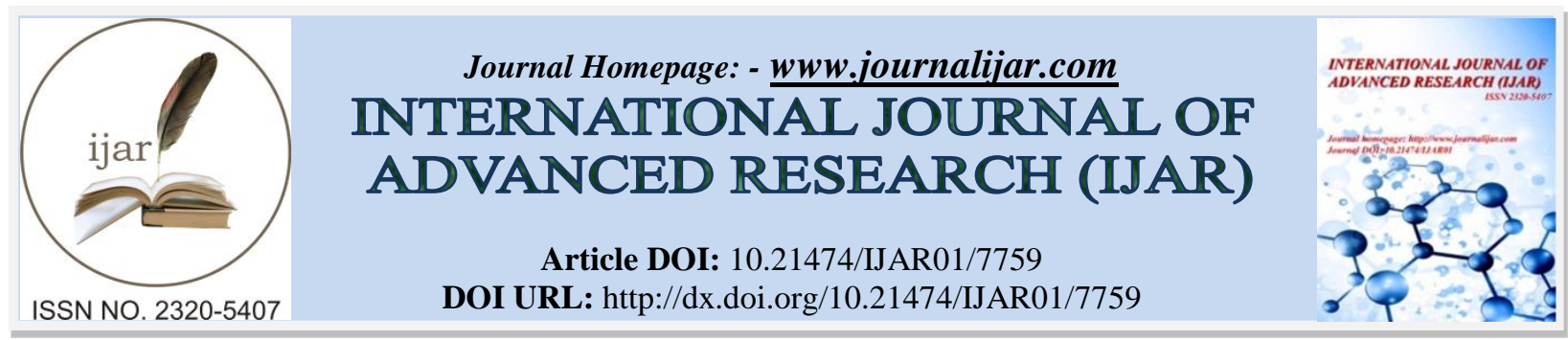

RESEARCH ARTICLE

\title{
CORNEAL ALTERATION IN EYES WITH PSEUDOEXFOLIATION SYNDROME.
}

\section{Dr. Tania Sadiq ${ }^{1}$, Prof. Dr. Syed Tariq Qureshi ${ }^{2}$, Dr. Arshi Nazir ${ }^{3}$ and Dr Anshulee Sood ${ }^{4}$.}

1. Postgraduate Scholar, Department of ophthalmology government medical college, srinagar.

2. Professor and Head, Department of ophthalmology government medical college, srinagar.

3. Registrar, Department of ophthalmology government medical college, srinagar.

4. Fellow, Department of ophthalmology government medical college, srinagar.

\section{Manuscript Info}

Manuscript History

Received: 24 July 2018

Final Accepted: 30 August 2018

Published: September 2018

Keywords:-

Corneal Endothelium, Corneal

Endothelial cell density,Central Corneal

Thickness, , Pseudoexfoliation .

\section{Abstract}

Background: Pseudoexfoliation syndrome (PXS) is an age-related systemic microfibrillopathy, caused by gradual deposition of extracellular grey and white material over various tissues .In pseudoexfoliation eyes, corneal endothelial changes are noted.Objective of Our study was to find corneal alterations among patients of Pseudoexfoliation syndrome of Kashmir region.

Material And Methods:After obtaining the ethical clearance from the institutional ethical committee, 150 patients withPseudoexfoliation were included in our Descriptive(Observational )study. Thorough ocular evaluation was done and corneal changes were noted including corneal endothelial cell density and Central corneal thickness using NON CONTACT specular microscope .Appropriate statistical tests were used for analyzing data.

Results:Pseudoexfoliation was predominantly seen in males . Mean Central corneal thickness in Pseudoexfoliation with glaucoma eyes was $(509.6 \pm 13.73 \mu)$ which was lower when compared with mean central corneal thickness in Pseudoexfoliation without glaucoma eyes $(523.5+17.15 \mu)$. The results when statistically analyzed were found to be significant. Also corneal endothelial cell density (2304 \pm 303 cells $/ \mathrm{mm}^{2}$ ) was lower in pseudoexfoliative eyes. Percentage of Hexagonal cells was $48.0 \pm 9.8(\%)$ and the $\mathrm{CV}$ was $38.3 \pm 5.8$ showing polymegathism and pleomorphism in these cells

Conclusion: Qualitative and Quantitative modifications in endothelial cells of eyes with PEX, particularly when IOP is high which may increase the risk of corneal decompensation after intraocular surgeries. In patients with PXG,evaluation of Corneal endothelial cell density and central corneal thickness should be done as the risk of underestimation of intra ocular pressure is high.

Copy Right, IJAR, 2018,. All rights reserved.

\section{Introduction:-}

Pseudoexfoliation (PEX) syndrome is an age related disease characterized by the widespread deposition of an abnormal extra cellular fibrillar material on many ocular and extra ocular tissues ${ }^{1}$. This condition was first described by a Finnish ophthalmologist named John Lindberg in 1917 in his doctoral thesis. Pseudoexfoliative

Corresponding Author:- Tania Sadiq.

Address:- Postgraduate Scholar, Department of ophthalmology government medical college, srinagar. 
material was first seen with the advent of slit lamp, Lindberg defined the greyish flecks and changes on the lens and pupillary margin of the iris ${ }^{2}$.

Pseudoexfoliation is present worldwide in every race and ethnic group with variable prevalence's. The reported prevalence of PEX rates varies extensively from $0 \%$ to more than $40 \%$. Prevalence of pseudoexfoliation are best obtained by population based studies, however useful information on the prevalence of pseudoexfoliation can be obtained from different sub groups of a population, such as patients with cataract and glaucoma ${ }^{4,5}$.

Other studies ${ }^{6}$ done in Kashmir valley coupled with our clinical observation led us to believe that the prevalence of PEX among Kashmiri population is relatively high. Therefore in a prospective study we set out to study the prevalence of pseudoexfoliation among Kashmiri patients with age related cataract who were scheduled for cataract surgery.

\section{Material And Methods:-}

The present study entitled "Corneal Alterations in eyes with Pseudoexfoliation syndrome" was conducted in the Postgraduate Department of Ophthalmology, Govt. Medical College, Srinagar. It is a prospective study and includes 150 patients with pseudoexfoliation syndrome. The diagnosis of Pseudoexfoliation was made based on, deposition of Pseudoexfoliation material on the pupillary margin or on the anterior capsule of lens.

\section{Exclusion Criteria:-}

1)mechanical or chemical trauma, 2) corneal degeneration and dystrophies, inflammation, 3) history of contact lens wear, 4) previous laser treatment, 5) Previous Surgery.

After enrolment a thorough clinical examination of both eyes including visual acuity both distant (Snellen's chart) and near (Jaeger's chart), slit lamp examination of anterior segment, schirmers test ,tear film break up time measurement, gonioscopy, applanation tonometry, fundoscopy, computerized perimetry with Humphrey field analyzer, specular microscopy, and systemic examination was done .

Corneal endothelial morphometry and central corneal thickness were studied using the non-contact Specular Microscope. The parameters under our study included): central endothelial cell density (ECD), which is the number of cells per square millimeter, coefficient of variation (C.V.), percentage of hexagonal cells and central corneal thickness (CCT).

PXS based on the presence of typical pseudoexfoliation material at the pupil border on undilated examination, on anterior lens capsule on dilated examination, or on the trabecular meshwork on Gonioscopy, with or without Sampaolesi's line and pigment deposition in angle and/or corneal endothelium Intra ocular pressure (IOP) was measured using Goldmann Applanation Tonometry, an average of three IOP readings were obtained prior to pupillary dilatation. Gonioscopy was performed in patients who had suspicious glaucomatous findings. A diagnosis of glaucoma was recorded if the patient had raised IOP $>21 \mathrm{mmHg}$ along with optic nerve head cupping and corresponding visual field defects.

\section{Statistical Methods:-}

The recorded data was compiled and entered in a spreadsheet (Microsoft Excel) and then exported to data editor of SPSS Version 20.0 (SPSS Inc., Chicago, Illinois, USA). Continuous variables were expressed as Mean \pm SD and categorical variables were summarized as frequencies and percentages. Student's independent t-test was employed for determining differences in continuous variables .

\section{Results:-}

A total of 150 eyes with evidence of Pseudoexfoliation were enrolled in the study which included 36 eyes with glaucomatous changes and 114 eyes without glaucoma. The demographic characteristics of the patients in the study are summarized in Table 1. 
Table 1:-Demographic characteristics of patients in the study

\begin{tabular}{|c|c|c|c|c|c|c|}
\hline \multirow[t]{2}{*}{ Age (years) } & \multicolumn{2}{|l|}{ Male } & \multicolumn{2}{|l|}{ Female } & \multicolumn{2}{|l|}{ Total } \\
\hline & No. & \%age & No. & $\%$ age & No. & \%age \\
\hline $40-50$ & 3 & 3.4 & 5 & 8.2 & 8 & 5.3 \\
\hline $51-60$ & 31 & 34.8 & 24 & 39.3 & 55 & 36.7 \\
\hline $61-70$ & 42 & 47.2 & 27 & 44.3 & 69 & 46.0 \\
\hline$>70$ & 13 & 14.6 & 5 & 8.2 & 18 & 12.0 \\
\hline Mean \pm SD & \multicolumn{2}{|c|}{$65.3 \pm 9.87$} & \multicolumn{2}{|c|}{$59.2 \pm 6.75$} & \multicolumn{2}{|c|}{$62.8 \pm 8.56$} \\
\hline
\end{tabular}

P-value $<0.001$ (Statistically Significant Difference)

The mean age of the subjects in the study was 62.8 years. Mean age of males was 65.3 years whereas of females was 59.2 years. Most of the patients were seen in the 61-70 years age group.There were more Males(89) with Pseudoexfoliationthan females(61) in the study. The average age at which Pseudoexfoliation was seen was higher in males than in females i.e., males developed the disease at later age than females and this was statistically significant $(\mathrm{p}<0.05)$.

Table 2:-Tear film break up time (TBUT) in patients with Pseudoexfoliation

\begin{tabular}{|c|c|c|}
\hline TBUT (Seconds) & No. & \%age \\
\hline$\leq 10$ & 42 & 28.0 \\
\hline $11-15$ & 68 & 45.3 \\
\hline$>15$ & 40 & 26.7 \\
\hline Total & 150 & 100 \\
\hline
\end{tabular}

Fourty two eyes had abnormal tear film break up time of $\leq 10$ seconds which accounts to $28 \%$ of the subjects taken in the study. Thus showing that PEX can decrease tear film stability time.

Table 3:-Corneal alterations in Pseudoexfoliation

\begin{tabular}{|c|c|c|}
\hline Corneal alterations & No. of eyes & \%age \\
\hline Climatic Droplet Keratopathy & 31 & 20.7 \\
\hline Guttae & 8 & 5.3 \\
\hline Pseudoexfoliative material on cornea & 7 & 4.7 \\
\hline
\end{tabular}

Climatic droplet keratopathy was seen in 31 eyes(20.7\%), followed by guttae in 8 eyes(5.3\%) and pseudoexfoliative material on cornea in 7 eyes.

Table 4:-Endothelial Characteristics of Pseudoexfoliative eyes

\begin{tabular}{|c|c|}
\hline Corneal Endothelial Characteristics & Mean \\
\hline Endothelial Cell Density $\left(\right.$ Cell $\left./ \mathrm{mm}^{2}\right)$ & $2304 \pm 303$ \\
\hline Hexagonal (\%) & $48.0 \pm 9.8$ \\
\hline Cell Variation in Cell Size & $38.3 \pm 5.8$ \\
\hline
\end{tabular}

The mean Endothelial Cell Density as observed during our study in Pseudoexfoliative Eyes was $2304 \pm 303$ cells $/ \mathrm{mm}^{2}$.

The mean of Hexagonal cells was $48.0 \pm 9.8(\%)$ and the CV was $38.3 \pm 5.8$. Thus showing polymegathism and pleomorphism in the cells of pseudoexfoliation patients.

Table 5:-Central Corneal Thickness in Pseudoexfoliative Eyes

\begin{tabular}{|l|c|}
\hline Central Corneal Thickness & Mean \\
\hline Pseudoexfoliation with Glaucoma & $509.6+13.73 \mu$ \\
\hline Pseudoexfoliation without Glaucoma & $523.5+17.15 \mu$ \\
\hline
\end{tabular}

Mean CCT in Pseudoexfoliation with glaucoma eyes $(509.6 \pm 13.73 \mu)$ was found to be lower when compared with Mean CCT in Pseudoexfoliation without glaucoma eyes $(523.5 \pm 17.15 \mu)$ and this was found to be statistically significant $(\mathrm{P}-$ value $<0.001)$. 


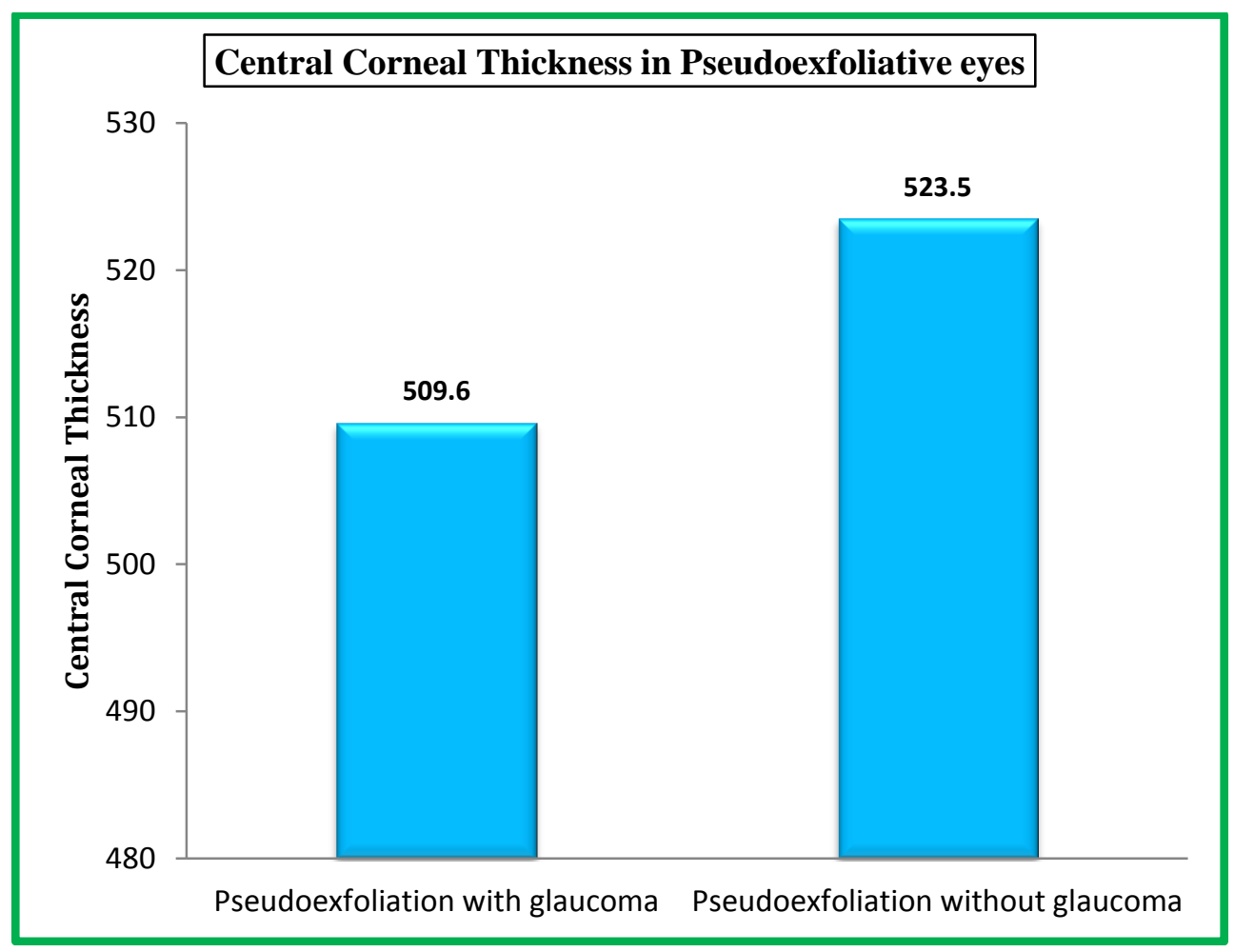

\section{Discussion:-}

In our study, we found that most of the Pseudoexfoliation syndrome patients enrolled were in the 61-70 age group and more males had pseudoexfoliation than females. Whereas in Saroj Sarwa et $\mathrm{al}^{7}$,pseudoexfoliation was seen in the age group of 55-80 years and males and females were equally invoved. Forsius H, Forsman E et $\mathrm{al}^{8}$ however noted in their study that there was rapid increase in the incidence of Pseudoexfoliation with age, especially after 50 years. Also Dr Chandra kanth ${ }^{9}$ et al found that increase in age is significantly associated with pseudoexfoliation. Whereas no sex predilection was seen.

We found climatic droplet keratopathy in 31 eyes which accounts to $20.7 \%$ of the study group.Thus showing a strong association with pseudoexfoliation. Dr Chandra Kanth et $\mathrm{al}^{9}$ noted that out of 50 pseudoexfoliation eyes ,7 had climatic droplet keratopathy.Whereas in their control group only 2 had the same. Resnikoff S, Filliard $\mathrm{G}^{10}$ found six times as many cases of exfoliation syndrome in persons with climatic keratopathy than in people without.Whereas Forsius H Forsman $\mathrm{E}$ et $\mathrm{al}^{8}$ did not find association between the two.

Also we noted that 42 eyes hadtear film break up time of $\leq 10$ secs. Thus showing that pseudoexfoliation can cause decrease in tear film secretion and disturb tear film stability. M Orcun Akdemir et $\mathrm{al}^{11}$ noted that tear fim break up time was 11 secs in PEX group and 8secs in PEX syndrome and PEX glaucoma group.Vassilios P.Kozobolis,Emmanouil $\mathrm{V}$ et al ${ }^{12}$ noted that tear film break up time was significantly lower i.e (8.6 secs )in pseudoexfoliation patients as compared to controls in whom it was 12.3 secs. Also Kozobolis VP, Detorakis et $\mathrm{al}^{13}$ found that the tear film break up times were significantly lower(6.91 secs) in Pseudoexfoliation syndrome.The mean Endothelial Cell Density as observed during our study in Pseudoexfoliative Eyes was 2304 \pm 303 cells / $\mathrm{mm}^{2}$. Thus showing significant modification in endothelial cellsof eyes with Pseudoexfoliation.Saroj Sarowa et al also showed decrease in endothelial cell density $\left(2124 \pm 116 \mathrm{cells} / \mathrm{mm}^{2}\right)$ in patients with pseudoexfoliation. Whereas Upender K Wali et al ${ }^{14}$ showed that mean endothelial cell density was $2438+-503.4$ cells $/ \mathrm{mm}^{2}$ in pseudoexfoliation with glaucoma patients and $2483 \pm 511.2 \mathrm{cells} / \mathrm{mm}^{2}$ in pseudoexfoliation without glaucoma patients. This difference was not found to be statistically significant.

The percentage of Hexagonal cells was $48.0 \pm 9.8(\%)$ which is lower and the CV was $38.3 \pm 5.8$ which is higher than we usually see in normal population. Thus showing that PEX Eyes have more polymegathism and 
pleomorphism as compared to normal population. Other studies showed similar results including Wang et $\mathrm{al}^{15}$, Seitz et al ${ }^{16}$, Quiroga et $\mathrm{al}^{17}$,Inoue et $\mathrm{al}^{18}$, Knorr in $1991^{19}$, Miyake et $\mathrm{al}^{20}$ and deJuan-Marcoset $\mathrm{al}^{21}$.

In this study, Mean CCT in Pseudoexfoliation with glaucoma eyes was $509.6 \pm 13.73 \mu$ which was found to be lower when compared with mean CCT in Pseudoexfoliation without glaucoma eyes 523.5 $\pm 17.15 \mu$. Mean CCT in Pseudoexfoliative eyes $(514.28 \pm 20.8 \mu)$ as compared with CCT in age matched normal population $(511.4 \pm 33.5 \mu)$ was seen in Vijaya L et al ${ }^{22}$.Similar results were given by Mohammed Ali Zare ${ }^{23}$ et al with CCT in PEX group $(511.9 \pm 27.9 \mu)$ and in control group $(531.4 \pm 32.7 \mu)$. Bozydar $\mathrm{T}$. Tomaszewski et al ${ }^{24}$ also showed that CCT in eyes with PEXG $(508.2+32.6 \mu)$ was thinner than in eyes with PEX syndrome without glaucoma $(529.7 \pm 30.3 \mu)$ and control group $(527.7 \pm 29.4 \mu)$. Thus showing that CCT was statistically significantly lower in PEXG group than in PEX syndrome and control group.Georgios et $\mathrm{al}^{25}$ in their study found CCT in Pseudoexfoliation with glaucoma eyes $(526 \mu)$ was significantly thinner compared to eyes with Pseudoexfoliation without glaucoma $(547.3 \mu)$.

Thus NONCONTACT specular microscopy quickly and easily without any side effects is a useful tool for screening of corneal endothelium in pseudoexfoliation patientssince PXS significantly influences cell density of corneal endothelium of people with this disease..

\section{Conclusion:-}

Our Study shows significant corneal alterations in patients of pseudoexfoliation. Therefore, all patients with pseudoexfoliative syndrome should be on regular follow up to detect glaucoma at an early stage. Patients with pseudoexfoliation are at increased risk of developing complications intraoperatively. Early diagnosis, detailed examination, knowledge of the complications and ability to manage these complications is key to success.

\section{References:-}

1. $\underline{\text { Akdemir MO}}, \underline{\text { Kirgiz A }}, \underline{\text { Ayar O }}, \underline{\text { Kaldirim H }}, \underline{\text { Mert M}}, \underline{\text { Cabuk KS }}$, Taskapili M. The Effect of Pseudoexfoliation and Pseudoexfoliation Induced Dry Eye on Central Corneal Thickness. Curr Eye Res. 2016;41(3):305-10.

2. BOŻYDAR T. TOMASZEWSKI, RENATA ZALEWSKA, AND ZOFIA MARIAK. EVALUATION OF THE ENDOTHELIAL CEll Density and the Central CoRneal Thickness in PSEUdoexfoliation Syndrome and PSEUdOEXFOLIATION GLAUCOMA.J OPHTHALMOL. 2014; 2014: 123683

3. De Juan-Marcosa L, Cabrillo-Estéveza L, Escudero-Domíngueza FA, Sánchez-Jaraa A, Hernández-Galilea E. Morphometric changes of corneal endothelial cells in pseudoexfoliation syndrome and pseudoexfoliation glaucoma. Arch Soc Esp Oftalmol 2013; 88(11):439-44.

4. Dr. Chandra Kanth, Dr. Sfoorti Goswami, Dr. Visalakshi Subramanian, Dr. Sudha Jeyaram, Dr. Naishadh Jivrajani, Dr. Vijay Bhaskar Gajjala. Association of Pseudoexfoliation (PXF) with Glaucoma and Climate Droplet Keratopathy (CDK . IOSR Journal of Dental and Medical Sciences.Volume 15, Issue 9 Ver. VIII (September). 2016), PP 31-33

5. Forsius H, Forsman E et al. Exfoliation syndrome: Frequency, gender distribution and association with climatically induced alterations of the cornea and conjunctiva Acta Ophthalmologica Scandinavica 2002 Oct; 80(5): 465.

6. Forsius H. Exfoliation syndrome in various ethnic populations. Acta Ophthalmol Suppl. 1988; 184: 71-85.

7. Forsius H. Prevalence of pseudoexfoliation of the lens in Finnes, Lapps, Icelanders, Eskimos and Russians. Trans Ophthalmol Soc UK 1979; 99: 296-298.

8. GeORgios K, Christos G ET AL. CENTRAL CORNEAL THICKNESS IN SUBJECTS WITH GLAUCOMA AND IN NORMAL INDIVIDUALS (WITH OR WITHOUT PSEUDOEXFOLIATION SYNDROME). CLINICAL OPHTHALMOLOGY. 2009; 1: 537 542.

9. Inoue K, Okugawa K, Oshika T, Amano S. Morphological study of corneal endothelium and corneal thickness in pseudoexfoliation syndrome. Jpn J Ophthalmol 2003;47(3):235-9.

10. Knorr HL, Jünemann A, Händel A, Naumann GO. Morphometric and qualitative changes in corneal endothelium in pseudoexfoliation syndrome. Fortschr Ophthalmol 1991;88(6):786-9.

11. Kozobolis VP, Detorakis et al. Evaluation of tear secretion and tear film stability in pseudoexfoliation syndrome. Acta Ophthalmol Scand 1999 Aug; 77(4): 406-9.

12. Lindberg TG. Clinical investigations on depigmentation of the pupillary border and translucency of the iris in cases of senile cataract and in normal eyes in elderly persons. Academic dissertation Helsinki 1917. Arch Ophthalmol 1989; 66 (Suppl 190): Helsinki University Press. 
13. Miyake K, Matsuda M, Inaba M. Corneal endothelial changes in pseudoexfoliation syndrome. Am J Ophthalmol 1989;108:49-52.

14. Mohammad Ali Zare, Ghasem Fakhraie, Fahimeh Asadi Amoli, Ali Abdollahi, Hadi Z-Mehrjardi. Central Corneal Thickness, Corneal Endothelial Cell Density, and Lens Capsule Thickness in Normotensive Patients with and without Pseudoexfoliation Syndrome. Iranian Journal of Ophthalmology Volume 24 / Number 2 / 2012

15. Quiroga L, Lansingh VC, Samudio M, Pena FY, Cater MJ. Characteristics of the corneal endothelium and pseudoexfoliation syndrome in patients with senile cataract. Clin Exp Ophthalmol 2010; 38:449-455.

16. Rashid W, Rather S, Singh T. Profile of patients of glaucoma in Kashmir valley: a hospital based study. JK Science July-September 2010; Vol. 12, No. 3.

17. Resnikoff S, Filliard G. Climatic droplet keratopathy, exfoliation syndrome and cataract. Br J Ophthalmol. 1991; 75: 734-6.

18. Ringvold A. Epidemiology of the pseudoexfoliative syndrome. Acta Ophthalmol Scand 1999; 77: $371-375$.

19. Ritch R and Schlotzer Scherhardt U. Exfoliation syndrome. Surv Ophthalmol 2001a; 45: 265-315.

20. Saroj Sarowa, Jaishri Murli Manoher, Kalpana Jain, Yamini Singhal, Deepak Devathia . Qualitative and quantitative changes of corneal endothelial cells and central corneal thickness in pseudoexfoliation syndrome and pseudoexfoliation glaucoma. International Journal of Medical Science and Public Health | 2016 | Vol 5 | Issue 12

21. Seitz B, Muller EE, Langenbucher A, Kus MM, Naumann GOH. Endothelial keratopathy in pseudoexfoliation syndrome: Quantitative and qualitative morphometry using automated video image analysis. Klin Monatsbl Augenheilkd 1995;207(3):167-75.

22. Upender K Wali, Abdullah S Al-Mujaini, Nadia S Al-Kharusi,Alexander A Bialasiewicz, and Syed G Rizvi.Quantitative and Qualitative Corneal Endothelial Morphology of Omani Patients with Pseudoexfoliation Syndrome.Sultan Qaboos Univ Med J. 2008 Nov; 8(3): 300-305.

23. Vassilios P. Kozobolis,Emmanouil V. Christodoulakis,Irene I. Naoumidi,Charalambo s S. Sigano,.Efstathios T. Detorakis,loannis G. Pallikaris.Study of conjunctival goblet cell morphology and tear film stability in pseudoexfoliation syndrome.Graefe's Archive for Clinical and Experimental Ophthalmology.June 2004, Volume 242, Issue 6, pp 478-483

24. Vijaya L et al. Central corneal thickness in adult south Indians. Chennai Glaucoma Study. 2010 Jan; 30-35.

25. Wang M, Sun W, Ying L. Corneal endothelial cell density and morphology in Chinese patients with pseudoexfoliation syndrome. Int J Ophthalmol 2012;5(2):186-9. 